\title{
Expansion of Semi-Automatic Processed Human Adipose-Derived Stem Cells in Medium Supplemented with Autologous Serum and Antioxidants
}

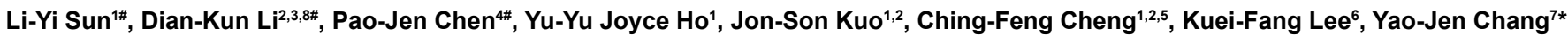 \\ and Cheng-Yoong Pang ${ }^{1,2 *}$
}

${ }^{1}$ Department of Medical Research, Buddhist Tzu Chi General Hospital, Hualien, Taiwan

2Institute of Medical Sciences, Tzu Chi University, Hualien, Taiwan

${ }^{3}$ Department of Hematology and Oncology, Taichung Tzu Chi General Hospital, Taichung, Taiwan

${ }^{4}$ Department of Obstetrics and Gynecology, Min-Sheng General Hospital, Taoyuan, Taiwan

5 Institute of Biomedical Sciences, Academia Sinica, Taipei, Taiwan

${ }^{6}$ Center for Medical Genetics, Buddhist Tzu Chi General Hospital, Hualien, Taiwan

${ }^{7}$ Department of Surgery, Taipei Tzu Chi General Hospital, Taipei, Taiwan

${ }^{8}$ Department of Medicine, College of Medicine, Tzu-Chi University, Hualien, Taiwan

\#These authors contributed equally to this study

\begin{abstract}
Objective: Excised fat tissue (EFT) is an excellent source of adipose-derived stem cells (ADSCs) for autologous cell therapy. However, the current technique for excising fat tissues with conventional surgical scissors and using culture medium containing fetal bovine serum (FBS) may not comply with Good Tissue Practice (GTP) guidelines. We thus developed a semi-automated process complying with the abovementioned guideline to manufacture clinicalgrade ADSCs from small volumes of EFT.
\end{abstract}

Methods: A semi-automated process was developed by using a disposable disperser tube operated on a Tube Disperser Workstation to obtain stromal vascular fraction (SVF) from EFT. A culture medium supplemented with human autologous serum (HAS) and mesenchymal stem cell culture adjuvant (MCA) consisted of basic fibroblast growth factor (bFGF/FGF-2) and antioxidants, was formulated to expand ADSCs from SVF in vitro.

Results: The semi-automated process can markedly enhance cell yields and reduce the operation time for mincing tissues from an hour down to a few minutes. The growth of ADSCs was slower in the $10 \%$ HAS medium than that in medium supplemented with FBS, but their growth in the 10\% HAS medium containing MCA (10\% HAS+MCA) was superior to both media. The $10 \%$ HAS+MCA medium also promoted adipogenesis, osteogenesis, chondrogenesis and increased the expression of CD44, CD73 and the stemness genes in the ADSCs.

Conclusion: Our novel semi-automated process provides an efficient isolation of SVF, and the $10 \%$ HAS+MCA medium accelerates the growth of ADSCs from small amounts of EFT without losing their differentiation ability.

Keywords: Disposable disperser tube; Adipose-derived stem cells; Antioxidants; Fibroblast growth factor-2; Autologous serum

Abbreviations: ADSCs: Adipose-derived Stem Cells; HAS: Human Autologous Serum; GTP: Good Tissue Practice; GMP: Good Manufacturing Practice; SVF: Stromal Vascular Fraction; MCA: Mesenchymal Stem Cell Culture Adjuvant; FBS: Fetal Bovine Serum; GVHD: Graft-Versus-Host Disease; AFT: Aspirated Fat Tissues; MSCs: Mesenchymal Stem Cells; BMI: Body Mass Index; EFT: Excised Fat Tissues; SFM: Serum-Free Medium; IRB: Institutional Review Board; IMDM: Iscove's Modified Dulbecco's Medium; NAC: N-acetylL-cysteine; AsA-2P: Ascorbic Acid-2-Phosphate; PI: Propidium Iodide; cbfa1: Core-Binding Factor Subunit Alpha-1; OC: Osteocalcin; COL IA1: Collagen Type I, Alpha 1; PPAR $\gamma$ : Proliferator-Activated Receptor Gamma; aP2: Adipocyte Fatty Acid-Binding Protein; ACAN: Aggrecan; COL IIA1: Collagen Type II, Alpha 1; ALP: Alkaline Phosphatase; SOX2: Sex-Determining Region Y-box 2; CXCR4: C-X-C Chemokine Receptor Type 4; TERT: Telomerase Reverse Transcriptase; FGF-2: Fibroblast Growth Factor-2; EGF: Epidermal Growth Factor; PDGF: Platelet-Derived Growth Factor; VEGF: Vascular Endothelial Growth Factor; HGF: Hepatocyte Growth Factor; IGFBP: Insulin-Like Growth Factor Binding Protein; IGF: Insulin-Like Growth Factor; PL: Platelet Lysate; p21: Cyclin-Dependent Kinase Inhibitor 1A; p27: CyclinDependent Kinase Inhibitor 1B.

\section{Introduction}

Freshly isolated, non-expanded stromal vascular fraction (SVF) is considered safe and effective for cell therapy [1,2]. Adipose tissue is an easily accessible and rich source of SVF [3-6]. Recently, autologous SVF has been clinically tested for breast reconstruction and augmentation [7], facial lipoatrophy [8], breast implant complications [9], depressed scars [10], traumatic calvaria defects [11], Crohn's disease fistulae [12] and graft-versus-host disease (GVHD) [13]. The SVF from these studies were isolated from aspirated fat tissues (AFT) by liposuction [14]. SVF contains mesenchymal stem cells (MSCs), namely adiposederived stem cells (ADSCs), which can differentiate into adipocytes,

*Corresponding authors: Cheng-Yoong Pang, Institute of Medical Sciences, Tzu Chi University, No. 701, Sec. 3, Zhongyang Rd., Hualien City 970, Hualien Taiwan, Tel: +886-3-8561825, ext. 5613; Fax: +886-3-8562019; E-mail: cypang@mail.tcu.edu.tw

Yao-Jen Chang, Department of Surgery, Buddhist Tzu Chi General Hospital Taipei Branch, No. 289, Jianguo Rd., Xindian Dist., New Taipei City 231 Taiwan, Tel: 886-2-66289779 ext. 5011; Fax: 886-2-6628-3316; E-mail: yjchang@tzuchi.com.tw

Received March 17, 2014; Accepted April 07, 2014; Published April 09, 2014

Citation: Sun LY, Li DK, Chen PJ, Ho YYJ, Kuo JS, et al. (2014) Expansion of Semi-Automatic Processed Human Adipose-Derived Stem Cells in Medium Supplemented with Autologous Serum and Antioxidants. J Stem Cell Res Ther 4 : 193. doi:10.4172/2157-7633.1000193

Copyright: (c) 2014 Sun LY, et al. This is an open-access article distributed under the terms of the Creative Commons Attribution License, which permits unrestricted use, distribution, and reproduction in any medium, provided the original author and source are credited. 
chondrocytes, osteoblasts, endothelial cells and keratocytes for further applications in regenerative therapy and tissue engineering $[2-4,15]$. However, only $1 \%-5 \%$ of cells from non-manipulated SVF will become ADSCs, which provides insufficient cell yield for patients with low body mass index (BMI).

ADSCs derived from the direct excision of orbital fat mass $[3,16]$ and buccal fat pad excised by surgery [17] compared to those isolated from lipoaspirated abdominal subcutaneous fat have similar differentiation potential [18]. Although the size of excised fat tissue (EFT) samples are commonly smaller, ADSC yields from EFT are often greater than that from AFT [6], suggesting that EFT could be an alternative source of ADSCs for individuals with lower BMI $[3,6,16,18]$. Currently, EFT must be minced manually with surgical scissors in a biological safety cabinet prior to further incubation with collagenase for SVF isolation $[3,18]$. The manual method presents major limitations including a lengthier time frame required to process the tissue for the extraction of SVF and variability in the resulting isolated cells due to intraoperator processing. The repeated use of surgical scissors also presents risks of cross-contamination. Several bench-top closed systems have been developed for SVF isolation from AFT [1], including the Cytori Celution $^{\mathrm{TM}}$ system [19] and the Tissue Genesis' TGI $1000^{\mathrm{TM}}$. However, an appropriate automated system for the isolation of SVF or ADSCs from EFT has yet to be developed.

Fetal bovine serum (FBS) are commonly used for the ex vivo expansion of MSCs, which is a potential source of zoonotic or other infectious agents such as prions, viruses and mycoplasma. FBS is a chemically ill-defined supplement with high batch-to-batch variability, which may lead to unpredictable cell growth or variation in differentiation [20-23]. On the other hand, the expansion of MSCs using human serum-supplemented medium is less efficient [24-25]. Several serum-free media (SFMs) have been recognized to be safe and free from animal products and related issues [26]. SFMs also do not affect the immunophenotype, proliferation potential and multipotency of ADSCs [22,27-33]. These SFMs include MesenCult ${ }^{\mathbb{B}}$ XF Medium (Stemcell Technologies, Canada) [34], StemPro ${ }^{\circledR}$ MSC SFM (Life Technologies, US), MSC Nutristem ${ }^{\circledR}$ XF Medium (Biological Industries, Israel) and BD Mosaic ${ }^{\mathrm{TM}}$ (Becton Dickinson, US). However, the cost of these SFMs and their lack of clinical validation limit their clinical applications.

Autologous cell transplantation is the best choice for patients who require cell therapy, where EFT harbors an excellent source of autologous ADSCs. We developed a semi-automated process complying with Good Tissue Practice (GTP) and Good Manufacturing Practice (GMP) guidelines to replace the current manual techniques to minimize human-induced variability and comply with clinical trial standards. In addition, we have also formulated a human autologous serum (HAS)- and antioxidant-supplemented medium for the expansion of ADSCs, and compared it with media containing either animal sera or HAS alone.

\section{Materials and Methods}

\section{Clean room}

Procedures for the isolation of SVF and expansion of ADSCs from EFT were conducted in Biological Safety Cabinets (Model 1286, Thermo Scientific Forma Class II Type A2, Thermo Scientific, Waltham, MA) in a clean room (ISO14644 Class 7) located in Gene and Stem Cell Production Laboratory of Hualien Buddhist Tzu Chi General Hospital.
Each suite is supported by positive-pressure (10-15 Pa), HEPA-filtered air, at a temperature of $22^{\circ} \mathrm{C}$ and relative humidity of $55-65 \%$. The flow suite is unidirectional, with entry and exit air locks. All personnel were trained in respect to the GMP guidelines.

\section{SVF isolation from EFT}

The experimental protocol was approved by the Institutional Review Board (IRB) of Min-Sheng General Hospital, Taoyuan, Taiwan. EFT from abdominal subcutaneous fat was obtained from 11 pregnant women (average age of $33.7 \pm 3.3$ ). About 25 grams of adipose tissues were collected from each donor, and the tissues were minced either by disposable disperser tubes (DT-20 gamma, IKA ULTRA TURRAX Tube drive, Staufen, Germany) or manually with surgical scissors. The process of isolation is shown in Figure 1. About 3 grams of EFT was resuspended in $12 \mathrm{~mL}$ of Iscove's modified Dulbecco's medium (IMDM; GIBCO-Invitrogen, Grand Island, NY), placed in a $15 \mathrm{~mL}$ disposable disperser tube, and homogenized by centrifugation at $1200 \mathrm{rpm}$ for 10 seconds thrice. Collagenase (Animal Origin Free)-A (LS004154, Worthington Biochemical Corporation, Lakewood, NJ; final concentration: $0.4 \mathrm{mg} / \mathrm{mL}$, volume: $15 \mathrm{~mL}$ ) was added for enzymatic digestion, and incubated in MO-01 hybridization oven (15 $\mathrm{rpm}, 37^{\circ} \mathrm{C}$; Double Eagle Enterprise, New Taipei City, Taiwan) for 8 hours (Figure 1D). After dispersing the digested adipose tissues several times with a $10 \mathrm{ml}$ sterile pipette (CORNING, Tewksbury, MA), the digested tissues were centrifuged at $2000 \mathrm{rpm}$ for $10 \mathrm{~min}$ to generate SVF pellets (Figure 1E and 1F). The SVF pellet was then resuspended in PBS and filtered through a $70 \mu \mathrm{m}$ strainer (Becton Dickinson, San Jose, CA) and the SVF cells were ready for ADSCs culture.

\section{ADSCs culture}

HAS was collected from each respective donor in Serum/Plain Tube (Cat\# 366430; Becton Dickinson) with informed consent. The SVF cells were propagated in MSC maintenance medium containing IMDM, 2 mM L-glutamine (GIBCO-Invitrogen), $2 \%$ or $10 \%$ HAS and MSC-culture adjuvant (MCA). The MCA is consisted of $10 \mathrm{ng} /$ $\mathrm{mL}$ fibroblast growth factor 2 (FGF-2, R\&D Systems, Minneapolis, $\mathrm{MN}$ ), $2 \mathrm{mM} \mathrm{N}$-acetyl-L-cysteine (NAC, Sigma, St. Louis, MO) and $0.2 \mathrm{mM}$ L-ascorbic acid-2-phosphate (AsA2P, Sigma). Other media consisted of IMDM, 2 mM L-glutamine with 10\% FBS (MSC-Qualified; GIBCO-Invitrogen) or $10 \%$ HAS, together with $10 \mathrm{ng} / \mathrm{mL}$ FGF-2 in all conditions, were used for comparison in the following assays (see below). The cells were cultured at $37^{\circ} \mathrm{C}$ in a humidified, $5 \% \mathrm{CO}_{2}$ incubator (Forma Series II Model 3110, Thermo Scientific). Cells at passages 1-3 of different donors were used in the following experiments.

\section{Cell number and viability assays}

For cell number and viability assays of SVF, cells were counted using an automatic cell counter, ADAM-MC (NanoEnTek, Seoul, Korea), with Propidium Iodide (PI) according to the manufacturer's instructions. For cell proliferation and viability assays, ADSCs were detached by trypsinization and then counted in triplicates using Vi-CELL AS cell counter (Beckman Coulter, Indianapolis, IN) as previously described [35]. For total ADSCs yield, the attached cells from SVF culture under various expansion media were detached by exposure to trypsin-EDTA on the $5^{\text {th }}$ day.

\section{Flow cytometric analysis}

For the characterization of cell surface phenotype, the ADSCs were cultured in $75 \mathrm{~cm}^{2}$ tissue culture flasks (Becton Dickinson) at an initial 


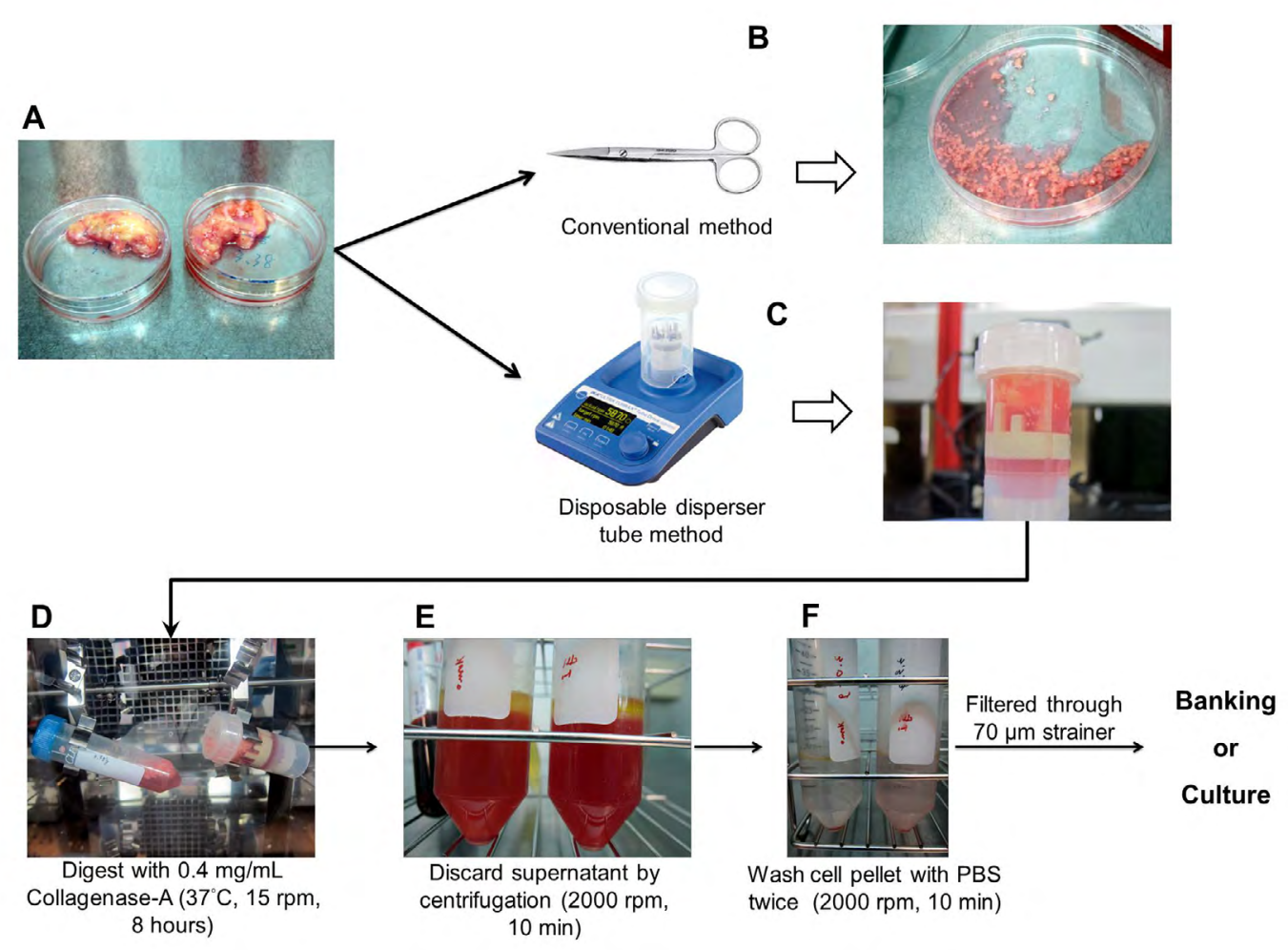

Figure 1: Overview of SVF isolation from fat tissues. In the following experiments, the fat tissues were all excised from abdominal subcutaneous tissues. (A) $3 \mathrm{~g}$ of the excised fat tissues were placed in the culture dishes and cut into small fragments either (B) by surgical scissors (conventional method) or (C) by disposable disperser tube method (our newly developed technique). (D) Samples were digested with collagenase in hybridization oven and (E-F) SVF pellets were generated by centrifugation.

density of 1000 cells $/ \mathrm{cm}^{2}$ in a humidified $5 \% \mathrm{CO}_{2}$ and $37^{\circ} \mathrm{C}$ incubator. After 6 days, single-cell suspensions were obtained by trypsinization, resuspended in culture medium, and further incubated at $37^{\circ} \mathrm{C}$ in $\mathrm{CO}_{2}$ incubator for 30 minutes. Cells were stained with anti-human CD13, CD34, CD44, CD73, CD90 and CD105 (Becton Dickinson) conjugated with fluorescein isothiocyanate or R-phycoerythrin for 1 hour at $4^{\circ} \mathrm{C}$ (for negative controls, primary antibodies were omitted). The expression profiles were examined by flow cytometry (FACSCalibur, Becton Dickinson) and analyzed by CXP Software (Beckman Coulter, CA).

\section{Analysis of gene expression and karyotyping}

After incubation under different culture media for 6 days $(n=3$ for each medium, initial cell density of 1000 cells $/ \mathrm{cm}^{2}$ ), the ADSCs were harvested to examine the expression of stemness and growth factor genes. Isolation of total RNA, cDNA synthesis and quantitative polymerase chain reaction ( $\mathrm{qPCR}$ ) were carried out as previously described [36]. Briefly, total RNA was isolated from cells using the RNeasy kit (Qiagen, Valencia, CA), and cDNA was synthesized from $10 \mu \mathrm{g}$ of total RNA using the Advantage RT-for-PCR kit (Clontech, Palo Alto, CA). qPCR and product detection were performed using the Fast Start Essential DNA Green Master (Roche, Indianapolis, IN) and the PikoReal Real-Time PCR System (Thermo Scientific) with the gene-specific primers as listed in Table 1. The results of amplification were analyzed using PikoReal 2.0 software (Thermo Scientific, PA). Gene expression levels were normalized to $\beta$-actin, which served as the internal control.
For karyotyping analysis, $75 \mathrm{~cm}^{2}$ tissue culture flasks seeded with ADSCs in $10 \%$ HAS+MCA-supplemented medium with an initial density of $3000 \mathrm{cells} / \mathrm{cm}^{2}$ were placed in a $\mathrm{CO}_{2}$ incubator. Once the cells reached $50-60 \%$ confluence, they were washed twice with phosphate buffered saline (PBS), detached by $0.25 \%$ trypsin-EDTA (Gibco BRL) and then replated at a density of 3000 cells $/ \mathrm{cm}^{2}$ under the same culture conditions. Karyotyping of ADSCs was performed following one month culture by established protocols [37].

\section{In vitro differentiation}

After incubation under various culture media conditions (10\% FBS, $10 \%$ HAS, $10 \%$ HAS+MCA or $2 \%$ HAS+MCA, $n=3$ for each medium) for 6 days, the ADSCs were seeded into 6-well plates (Becton Dickinson) for differentiation assays. Osteogenesis, adipogenesis and chondrogenesis of ADSCs were induced according to established protocols $[38,39]$. Osteogenic differentiation was evaluated by alkaline phosphatase (ALP) staining and the expression of $c b f a 1$ (core-binding factor subunit alpha-1), OC (osteocalcin) and COL IA1 (collagen type I, alpha 1) on day 14. Adipogenic differentiation of ADSCs was evaluated using Oil red $\mathrm{O}$ staining and the expression of PPARY (proliferatoractivated receptor $\gamma$ ) and $a P 2$ (adipocyte fatty acid-binding protein) on day 7. Chondrogenic differentiation was evaluated using Alcian Blue (Sigma) staining of sulfated proteoglycan-rich matrix (blue color) and the expression of ACAN (aggrecan) and COL IIA1 (collagen type II, alpha 1) on day 14. Methods for ALP staining, Oil red O staining and Alcian Blue staining were as reported previously $[4,33,35]$. 


\begin{tabular}{|c|c|c|}
\hline Gene & Primer sequences & Product size (bp) \\
\hline$\beta$-actin & $\begin{array}{l}\text { S: } 5^{\prime} \text { - CGCCAACCGCGAGAAGAT-3' } \\
\text { A: } 5^{\prime} \text { - CGTCACCGGAGTCCATCA -3' }\end{array}$ & 168 \\
\hline Nanog & $\begin{array}{l}\text { S: } 5^{\prime} \text {-AATACCTCAGCCTCCAGCAGAT-3' } \\
\text { A: } 5^{\prime} \text {-TGCGTCACACCATTGCTATTCTT-3' }\end{array}$ & 148 \\
\hline sox2 & $\begin{array}{l}\text { S: } 5^{\prime}-\text { CCTCCGGGACATGATCAG-3' } \\
\text { A: } 5^{\prime}-\text { TTCTCCCCCCTCCAGTTC-3' }\end{array}$ & 178 \\
\hline TERT & $\begin{array}{l}\text { S: } 5^{\circ} \text { - AGTGGATTCGCGGGCACAGA-3' } \\
\text { A: } 5^{\circ} \text { - TTCCCACGTGCGCAGCAGGA-3' }\end{array}$ & 257 \\
\hline CXCR4 & $\begin{array}{l}\text { S: } 5^{\circ} \text {-CGTGGAACGTTTTTCCTGTT-3' } \\
\text { A: } 5 \text {-TGTAGGTGCTGAAATCAACCC-3" }\end{array}$ & 129 \\
\hline IGF-1 & $\begin{array}{l}\text { S: } 5^{\circ} \text {-AAGATGCACACCATGTCC-3’' } \\
\text { A: } 5^{\circ} \text {-TGTTGAAATAAAAGCCCCTG-3' }\end{array}$ & 157 \\
\hline$H G F$ & $\begin{array}{l}\text { S: } 5^{\circ} \text {-TGTTCCCTTTTTTGGGTAAGC-3' } \\
\text { A: } 5^{\circ} \text {-CCCATTTGCCACAGAAAGTT-3" }\end{array}$ & 148 \\
\hline$E G F$ & $\begin{array}{l}\text { S: } 5^{5} \text {-CTAATCACCTACTCAATGCCTGG-3' } \\
\text { A: } 5^{\circ} \text {-TGATTCTCCCAGTACTCTTACTTGG-3' }\end{array}$ & 109 \\
\hline$O C$ & $\begin{array}{l}\text { S: } 5^{\circ} \text {-CAAAGTCTAACTAGGGATACC-3' } \\
\text { A: } 5^{\circ} \text {-AGAGATGAGTCTGTCCTG-3' }\end{array}$ & 150 \\
\hline Cbfa1 & $\begin{array}{l}\text { S: } 5^{\prime} \text {-TGGCAGCACGCTATTAAATC-3' } \\
\text { A: } 5^{\circ} \text {-TCTGCCGCTAGAATTCAAAA-3' }\end{array}$ & 103 \\
\hline COL IA1 & $\begin{array}{l}\text { S: } 5^{\circ} \text { - GACTCTAAGATCAGAGACGGAGAC-3' } \\
\text { A: } 5^{\circ} \text { - TCGCTGACATCTCCATTCATTCAC- } 3^{\circ}\end{array}$ & 250 \\
\hline PPARY & $\begin{array}{l}\text { S: } 5^{\prime} \text {-TTGCTGTCATTATTCTCAGTGGA-3' } \\
\text { A: } 5^{\circ} \text {-GAGGACTCAGGGTGGTTCAG-3' }\end{array}$ & 124 \\
\hline$a P 2$ & $\begin{array}{l}\text { S: } 5^{\prime} \text {-CAATCTAGCAGACGGAACTGAA-3'} \\
\text { A: } 5^{\prime} \text {-CCGTTTGAATTTTCCAATAAGTTT-3' }\end{array}$ & 76 \\
\hline$A C A N$ & $\begin{array}{l}\text { S: } 5^{\prime} \text {-TACACTGGCGAGCACTGTAAC-3’' } \\
\text { A: } 5^{\prime} \text {-CAGTGGCCCTGGTACTTGTT-3' }\end{array}$ & 71 \\
\hline$C O L \| A 1$ & $\begin{array}{l}\text { S: } 5^{\prime} \text {-GAATAGCACCATTGTGTAGGAC-3' } \\
\text { A: 5'-AATGCCCCCTGAGTGAC-3' }\end{array}$ & 97 \\
\hline
\end{tabular}

\section{S: Sense; A: Antisense}

Table 1: Primers used for quantitative polymerase chain reaction.

\section{Cytokine and growth factor array}

Human cytokines and growth factors from culture supernatants were detected and quantitated using Human Cytokine Antibody Array 1 (Cat \#AAH-GF-1, RayBiotech, Norcross, GA) according to the manufacturer's instructions. Cytokine and growth factor expression from culture supernatants were quantified by ImageJ $1.40 \mathrm{~g}$ software $(\mathrm{NIH})$, using the positive control (POS) on the same membrane as the internal control. Data are presented as the relative ratio of cultured to un-cultured groups.

\section{Statistical analysis}

Statistical analysis for cell proliferation, gene expression and cytokine contents in supernatants were performed with Microsoft Excel using t-tests. Cell numbers and viabilities following extraction via the two differential methods were analyzed with Wilcoxon signed rank test using Prism 4 (GraphPad Software, CA). $p<0.05$ was considered statistically significant. Experiments were performed at least twice, and each data point is presented as mean $\pm \mathrm{SD}$.

\section{Results}

\section{SVF isolation from EFT by disposable disperser tubes}

We have developed a novel semi-automated method to isolate SVF from EFT. For comparison, the EFT was minced either with surgical scissors (Figure 1B) or by the semi-automated disposable disperser tubes (Figure 1C). The processed fat tissues were then digested with collagenase for 8 hours (Figure 1D). Finally, SVF cells were isolated from the digested fat tissues by centrifugation into cell pellets (Figure $1 \mathrm{E}$ and $1 F$ ). The semi-automated disposable tube tissue dispersion method reduced the operation time for mincing tissue from approximately one hour to a few minutes, and also avoided the use of scissors, a potential source of contaminants.

\section{Cell yield and viability of SVF and ADSCs prepared using the semi-automated tube disperser and manual operation}

The yield and viability of SVF and ADSCs prepared using either the semi-automated tube disperser method or the manual operation with surgical scissors was compared in 9 donors (Figure 2). Three grams of fat tissues were used for both methods. To compare total yield of ADSCs, SVF cells were seeded at the same initial cell density $\left(10,000 \mathrm{cells} / \mathrm{cm}^{2}\right)$ and incubated in $10 \%$ HAS+MCA-supplemented medium for 5 days, and then detached using trypsin-EDTA. The cell yield of SVF prepared using tube disperser was 1.3-10.2 folds higher than the conventional method. The cell viability of SVF prepared using tube disperser was 0.9-2.4 folds higher than the conventional method (Figure 2A). Moreover, the total yield of ADSCs was 1.2-7.8 folds higher when compared to the conventional method, and the
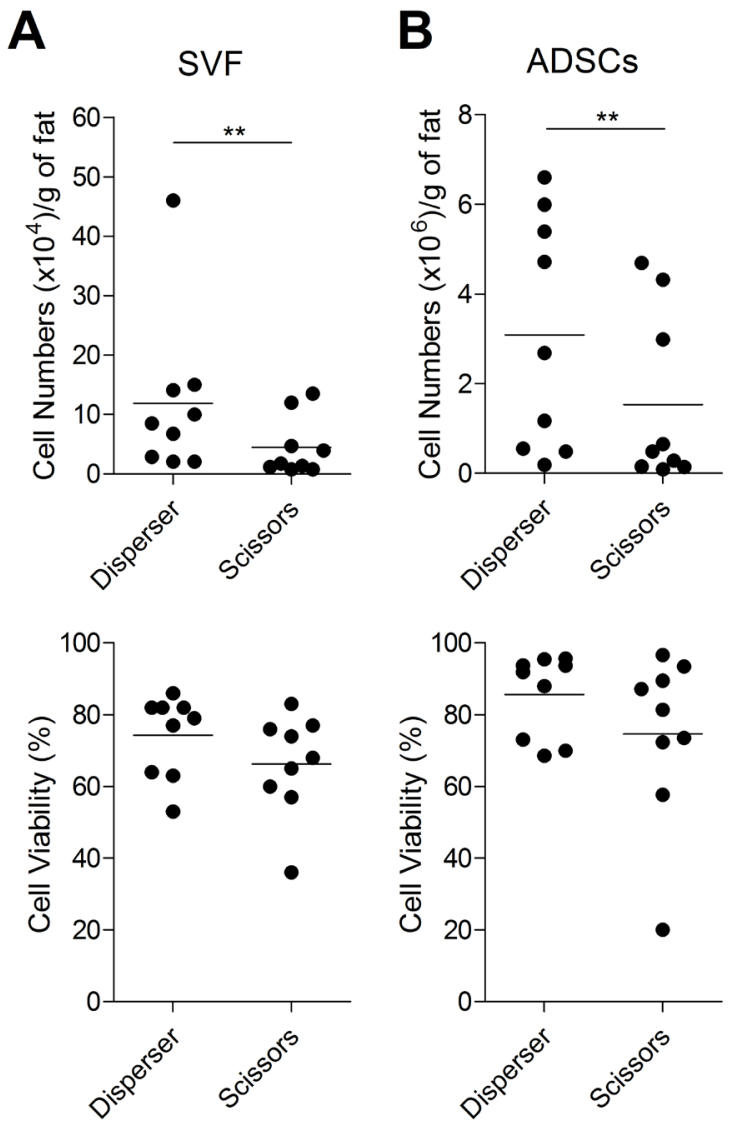

Figure 2: Yield of SVF cells and ADSCs from the excised fat tissue (EFT) by the 2 methods. (A) Following SVF isolation, the cell numbers and viability were counted using an automated cell counter Adam-MC with $\mathrm{PI}$. (B) The isolated SVF were propagated and the resulting ADSC populations were cultured for 5 days. Cells numbers and viability were collected using an automated cell counter Vi-CELL AS with the trypan blue dye. Data were analyzed by Wilcoxon signed rank test, ${ }^{* *} p<0.01$. Data show results from 9 donors and bars represent population averages. 
cell viability was $0.8-4.8$ folds higher (Figure $2 \mathrm{~B}$ ). Although the cell viability did not significantly differ between the two methods for both SVF and ADSCs ( $p=0.25, p=0.3594$, respectively), the total yields were significantly higher for both SVF and ADSCs using the tube disperser method ( $p=0.0039, p=0.0039$, respectively; Figure 2).

\section{ADSCs expansion in different culture media}

We compared the growth of ADSCs in the medium containing $10 \%$ HAS and $10 \%$ FBS, and found that the growth is slower in the $10 \%$ HAS-supplemented medium (Figure 3B). To improve the growth of ADSCs without the use of animal serum, we added two antioxidants (NAC and AsA2P) to the HAS-supplemented medium, where FGF2, NAC and AsA2P supplements were collectively named MCA as previously described [37]. The morphology and growth of ADSCs between the following conditions were compared: 10\% FBS, 10\% HAS, $10 \%$ HAS+MCA and 2\% HAS+MCA. ADSCs were found to maintain their spindle-shaped morphology under all conditions on day 3 (Figure $3 \mathrm{~A})$. ADSC expansions in the $10 \%$ HAS+MCA condition significantly increased from $155 \%$ to $324 \%$ between days 1 to 7 as compared to the $10 \%$ HAS condition (Figure 3C). However, ADSC expansions in the $2 \%$ HAS+MCA condition markedly decreased when compared to the $10 \%$ HAS+MCA condition (Figure 3D).

Karyotyping, stemness genes, stem cell-related genes, and growth factor genes of ADSCs

Karyotypes of ADSCs from 2 donors after cultured in 10\%
A

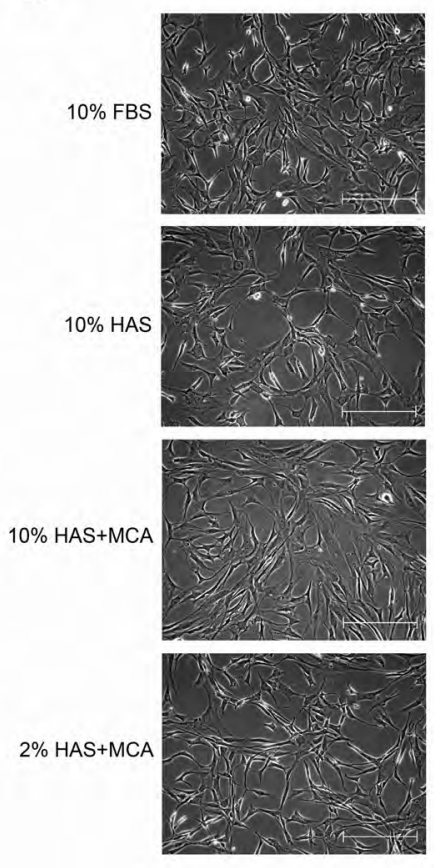

B

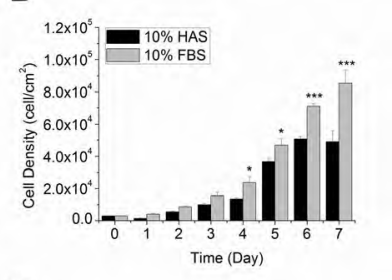

C

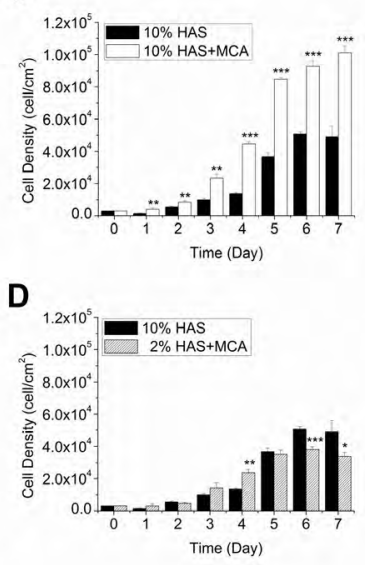

Figure 3: The growth of ADSCs prepared by the tube dispersion method cultured with different media. (A) Direct visualization of cell culture and cell morphology on day 3 . Bar $=500 \mu \mathrm{m}$. ADSC proliferation were examined by a time course of cell densities under the 10\% FBS, 10\% HAS, 10\% HAS+MCA and $2 \%$ HAS+MCA conditions between days $0-7$. (B) $10 \%$ FBS vs. $10 \%$ HAS (C) $10 \%$ HAS+MCA vs. $10 \%$ HAS alone. (D) $2 \%$ HAS+MCA vs. $10 \%$ HAS alone. Data are shown as mean $\pm \operatorname{SD}(n=3) .{ }^{*} p<0.05 .{ }^{* *} p<0.01 .{ }^{* * *} p<0.005$.
HAS+MCA-supplemented medium for 1 month were shown in figure $4 \mathrm{~A}$ and $4 \mathrm{~B}$. No abnormality was observed. The expression of 2 stemness genes (Figure 4C), 2 stem cell-related genes (Figure 4D), and 3 growth factors (Figure $4 \mathrm{E}$ ) of ADSCs maintained in various culture supplements were compared. The expression of Nanog, SOX2 (sexdetermining region Y-box 2), CXCR4 (C-X-C chemokine receptor type 4), TERT (telomerase reverse transcriptase), IGF-1, HGF, and $E G F$ were enhanced in the 10\% HAS-, 10\% HAS+MCA- and $2 \%$ HAS+MCA-supplemented media as compared to those in the $10 \%$ FBS-supplemented medium (Figure 4C and 4D).

\section{Osteogenic, chondrogenic and adipogenic differentiations}

Following culturing in differentiation-inducing media, the differentiation status of ADSCs was assessed. Alkaline phosphatase staining (Figure 5A) and von Kossa staining (Figure 5B) revealed the osteogenic differentiation of ADSCs. Expression of several osteogenic genes (i.e. cbfa 1, OC and COL IA1) after osteogenic induction was also studied (Figure 5C). In general, the expression of these genes increased for all HAS-containing conditions as compared to those in the FBSsupplemented medium. Sulfated proteoglycan-rich matrix (alcian blue staining), indicating chondrogenic differentiation, was the highest in ADSCs cultured in the 2\% HAS+MCA condition (Figure 6A) Expressions of ACAN and COL IIA1 increased significantly in ADSCs cultured in the 10\% HAS+MCA- and 2\% HAS+MCA-supplemented media (Figure 6B). Oil Red O-positive lipid vacuoles, indicating adipogenic differentiation, were evident in ADSCs for all conditions (Figure 6C). The expression of PPAR $\gamma$ increased in ADSCs cultured in the 10\% HAS+MCA- and 2\% HAS+MCA-supplemented media, while the expression of $a P 2$ was increased only in the $10 \%$ HAS+MCA condition (Figure 6D). Thus, following the addition of differentiating media, ADSCs conditioned in both HAS and MCA further promoted all three types of differentiation when compared to ADSCs conditioned in media supplemented with FBS or HAS alone.

\section{Surface markers of ADSCs}

We have examined the phenotype of ADSCs grown in different culture conditions at passage 1 (Figure 7A) and passage 2 (Figure 7B) for the identification of MSCs. The expression levels of CD44 and CD73 were higher on ADSCs grown in the HAS-containing media (10\% HAS, $10 \%$ HAS+MCA or $2 \%$ HAS+MCA) compared with those grown in the FBS-supplemented medium during passage 1 , whereas the expression level of CD90 was lower on ADSCs grown in all HAS-containing media as compared with those grown in the FBS-supplemented medium. In addition, only ADSCs grown in the FBS-supplemented medium expressed CD34 at passage 1. These differences in expression levels between the HAS- and FBS-containing media were small but steady during passage 1 . However, no differences in the expression of these markers were found during passage 2 .

\section{Cytokine profiles of ADSCs}

Finally, we used a commercially available antibody array to compare the secretion of 41 growth factors between the supernatant of ADSCs grown in the 10\% HAS- and 10\% HAS+MCA-supplemented media for 4 days. FGF-2, epidermal growth factor (EGF), plateletderived growth factor (PDGF) isoforms $\mathrm{AA}, \mathrm{AB}$ and $\mathrm{BB}$, and vascular endothelial growth factor (VEGF) R3 in the supernatant decreased after 4 days of culture in the 10\% HAS condition. Hepatocyte growth factor (HGF), insulin-like growth factor binding proteins (IGFBP)-1, IGFBP-4, IGFBP-6, insulin-like growth factor (IGF)-1 and VEGF 
A
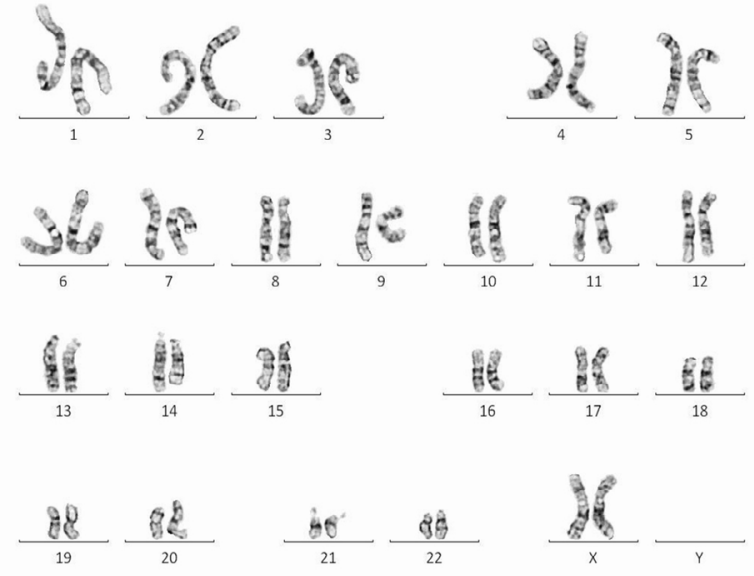

C
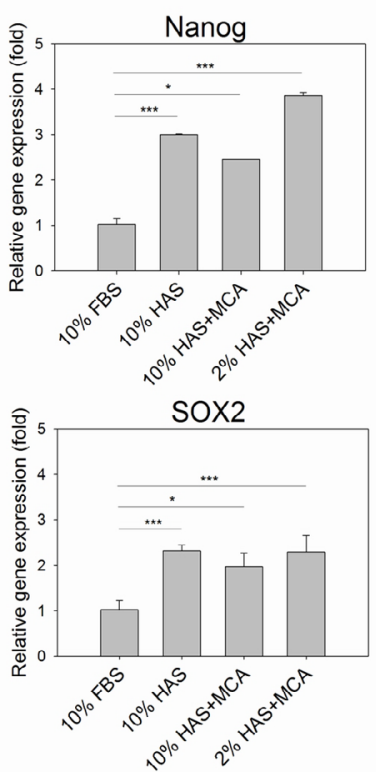

D
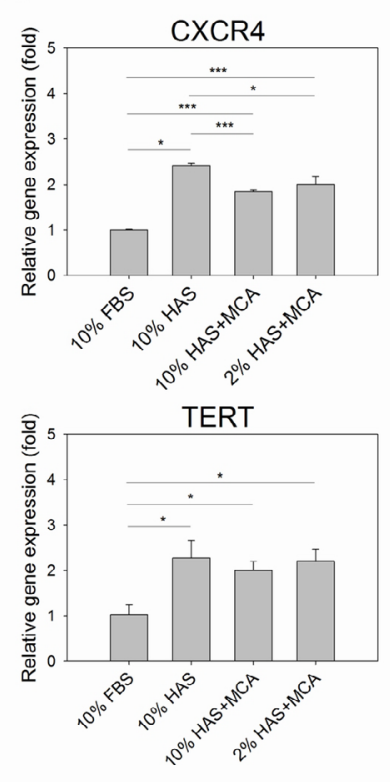

B
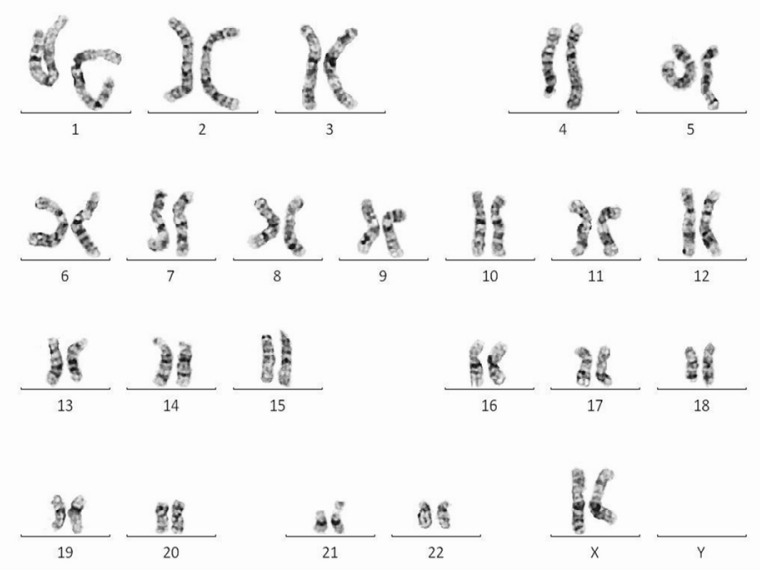

E
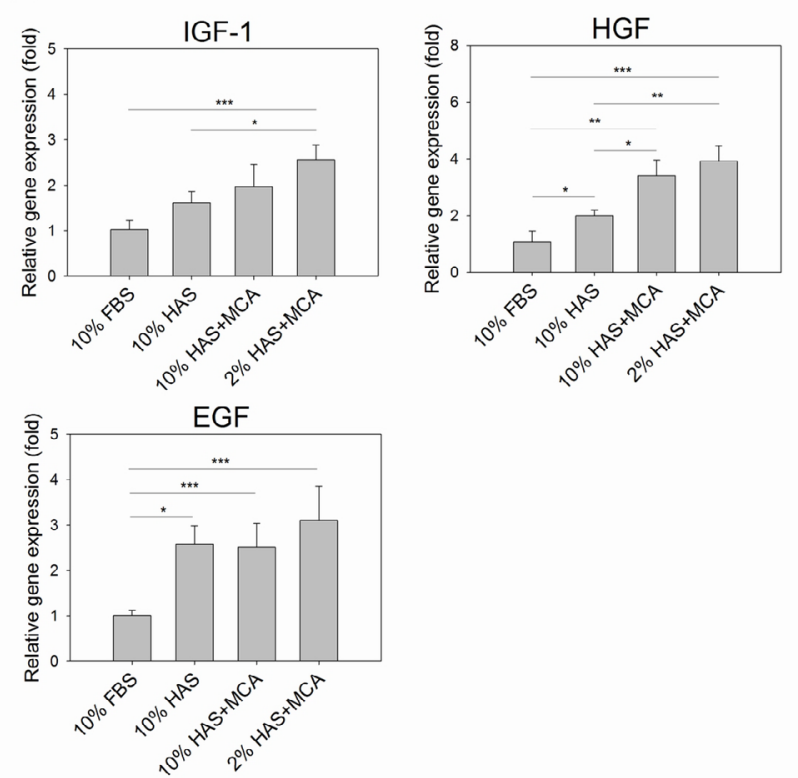

Figure 4: Karyotype and the expression of stemness genes and growth factor genes of ADSCs. (A, B) Karyotyping analyses were carried out using ADSCs from donors 3 and 8 following culturing in 10\% HAS+MCA-supplemented medium for 1 month. Quantitative PCR were performed to quantify the relative gene expression of (C) the stemness genes: Nanog, SOX2, (D) the stem cell-related genes: CXCR4, TERT, and (E) the growth factor genes: IGF-1, HGF and EGF in the ADSCs that were cultured in the different culture media for 7 days $(n=3)$. The gene expression was normalized to $\beta$-actin, serving as the internal control, and made relative to the expression levels of each gene measured for cells cultured under the $10 \%$ FBS condition. Each bar represents means \pm SD. ${ }^{*} p<0.05 .{ }^{* *} p<0.01$. ${ }^{* \star *} p<0.005$.

increased after 4 days of culture in the $10 \%$ HAS condition (Figure $8 \mathrm{~A}$ and $8 \mathrm{~B})$. Comparing between the $10 \%$ HAS and $10 \%$ HAS+MCA conditions, PDGF-AA, PDGF-AB and PDGF-BB content found in the supernatant decreased in the $10 \%$ HAS+MCA condition, while the VEGF R3 increased. At the same time, the secretion of HGF and VEGF increased in the 10\% HAS+MCA condition and the secretion of IGF-1 and IGFBP-4 decreased (Figure $8 \mathrm{C}$ ). These results indicate that MCA can affect the autocrine and/or paracrine activities of the ADSCs in the microenvironment.

\section{Discussion}

The development of GTP/GMP processes for the isolation of SVF or ADSCs using small amount of EFT represents a major advance in the fields of cell therapy and tissue engineering. However, the current manual operation with surgical scissors in EFT processing has serious limitations. To minimize these limitations, we developed a semiautomated tissue processing method for the isolation of SVF (Figure 1). This semi-automated process has three important advantages. First, the new process can markedly reduce the operation time for mincing tissues from one hour down to a few minutes. Second, the yields of SVF and ADSCs can be increased by the semi-automatic protocol. Third, the use of a disposable disperser tube instead of surgical scissors (requiring repeated disinfection and aseptic validation) eliminates a potential source of contamination. To the best of our knowledge, this 
Citation: Sun LY, Li DK, Chen PJ, Ho YYJ, Kuo JS, et al. (2014) Expansion of Semi-Automatic Processed Human Adipose-Derived Stem Cells in Medium Supplemented with Autologous Serum and Antioxidants. J Stem Cell Res Ther 4: 193. doi:10.4172/2157-7633.1000193

A

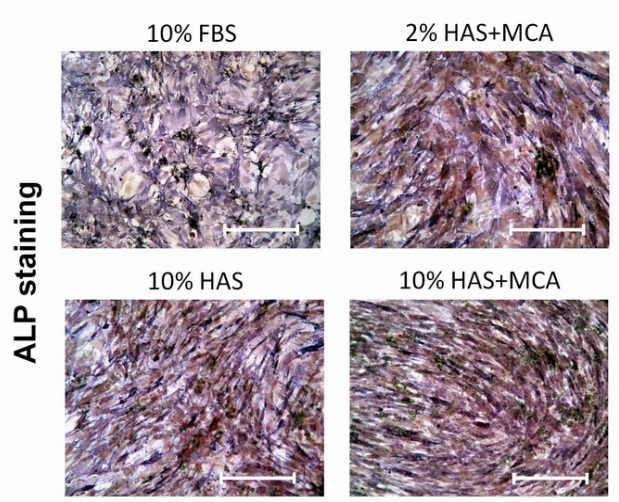

B

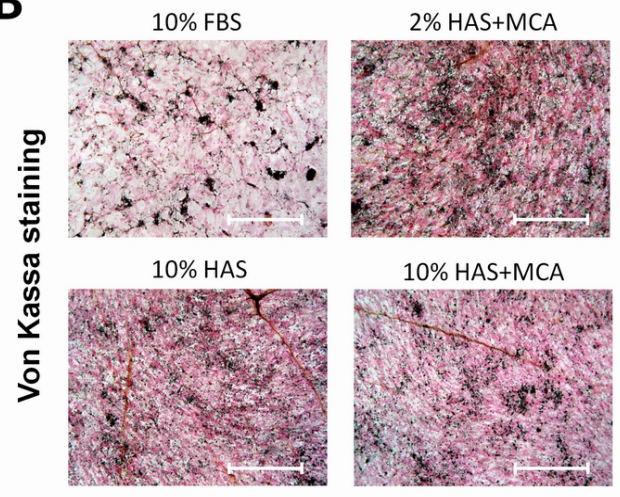

C

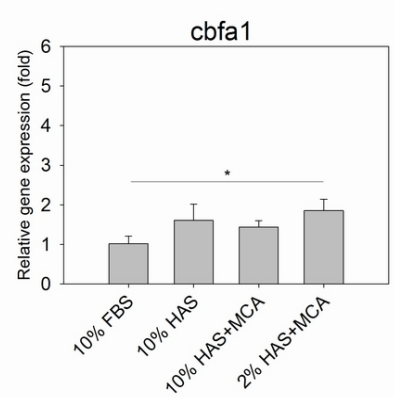

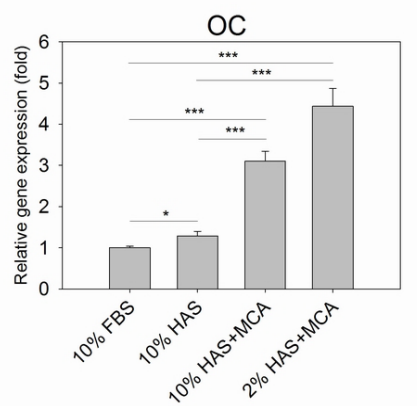

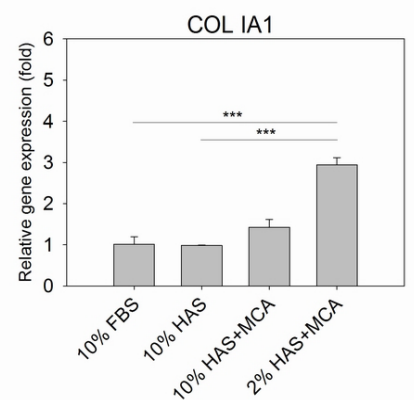

Figure 5: The osteogenic differentiation of the ADSCs. After incubation in the different culture media for 6 days ( $n=3)$, the ADSCs were then exposed to the differentiation medium for 14 days and examined for their osteogenic differentiation. Photomicrographs show alkaline phosphatase (ALP) activity (A) and von Kassa staining (B) of the ADSCs. Bar=500 $\mu \mathrm{m}$. Both ALP and von Kassa staining demonstrate osteo-differentiation of the ADSCs. (C) The expression of osteogenesis-associated genes in the ADSCs quantified by quantitative PCR analyses, using $\beta$-actin as the internal control. Each bar represents mean cell density \pm SD. ${ }^{*} p<0.05$. ${ }^{* *} p<0.01$. ${ }^{* *} p<0.005$.

A

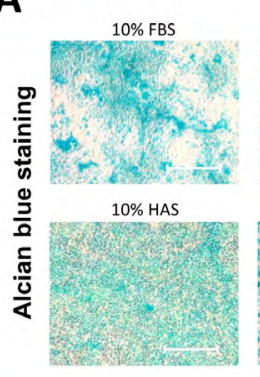

C
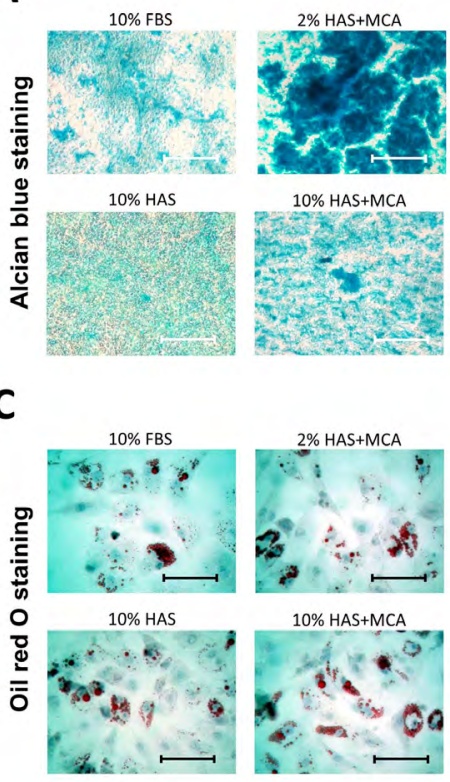

B

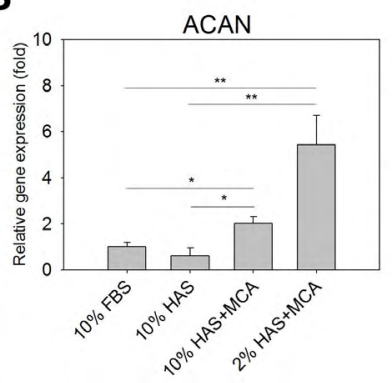

D

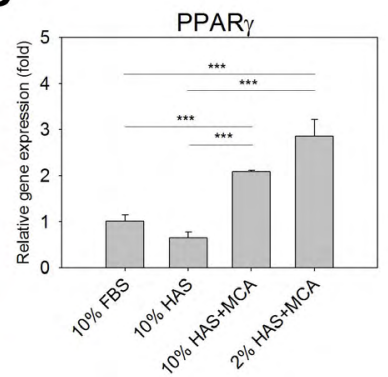

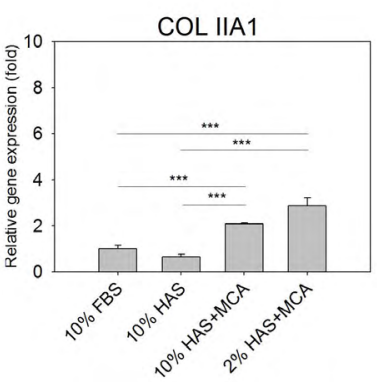

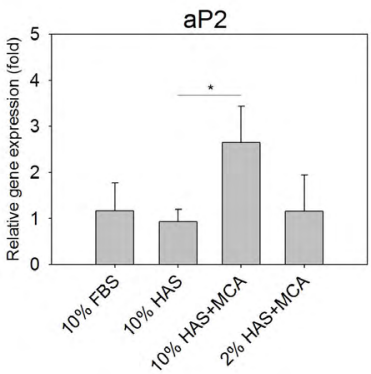

Figure 6: Chondrogenic and Adipogenic differentiation of the ADSCs. After incubation under the different culture media for 6 days ( $n=3$ ), the ADSCs were then exposed to the chondrogenesis and adipogenesis differentiation medium for 14 and 7 days, respectively. (A) Photomicrographs show sulfated proteoglycan-rich matrix (blue color) indicating chondrogenic differentiation in the ADSCs at day 14. (B) The expression of chondrogenesis-associated genes (ACAN and COL IIA1) at day 14. (C) Photomicrographs show lipid spheres (by Oil Red $\mathrm{O}$ staining) indicating adipogenic differentiation in the ADSCs at day 7 . (D) The expression of adipogenesisassociated genes (PPARY and $a P 2)$ in the ADSCs at day 7 . For $(A / C)$, bar=500 $\mu \mathrm{m}$. For (B/D), $\beta$-actin was the internal control and each bar represents mean cell density $\pm \operatorname{SD}(n=3) .{ }^{*} p<0.05 .{ }^{* *} p<0.01 .{ }^{* * *} p<0.005$. 
A
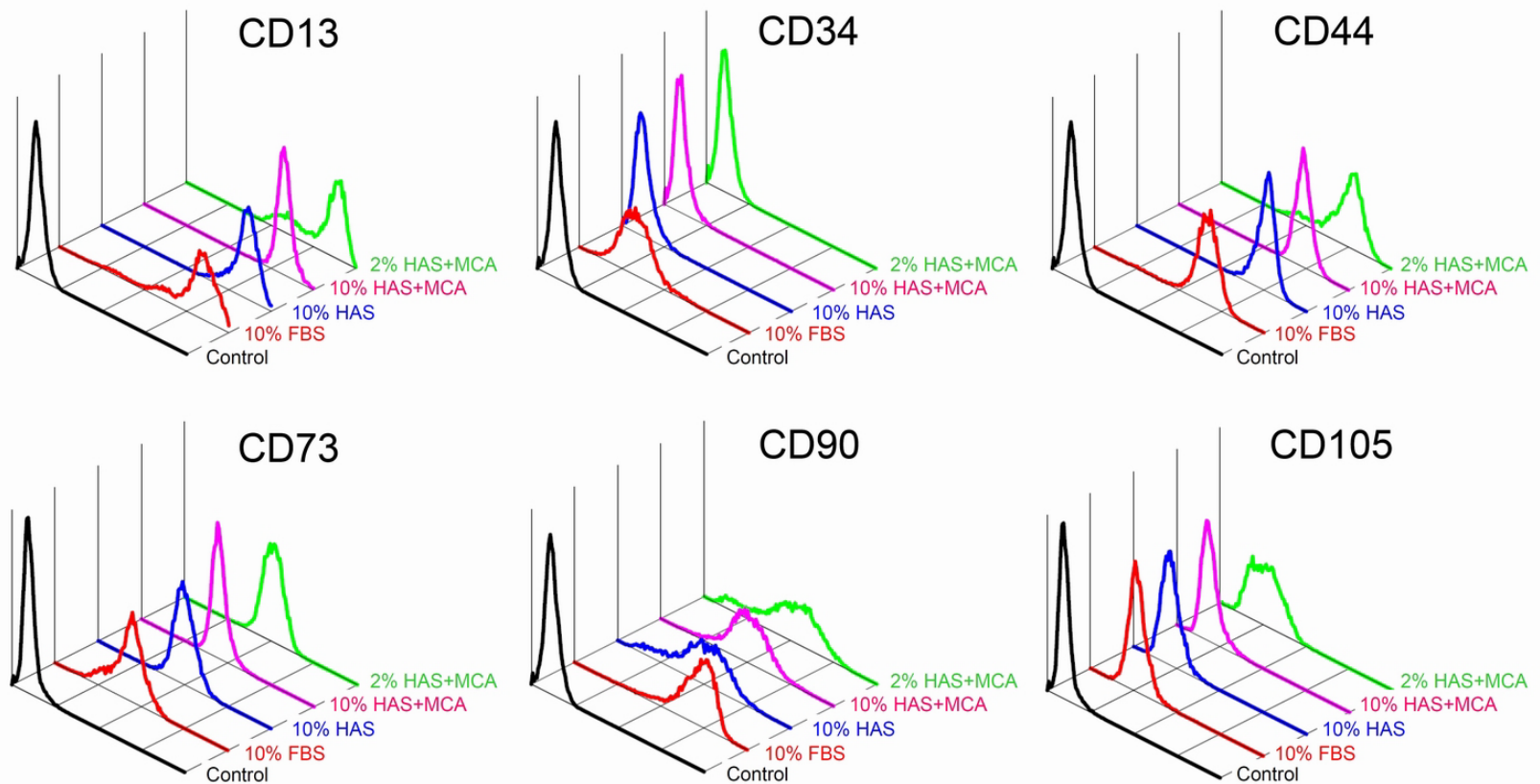

B
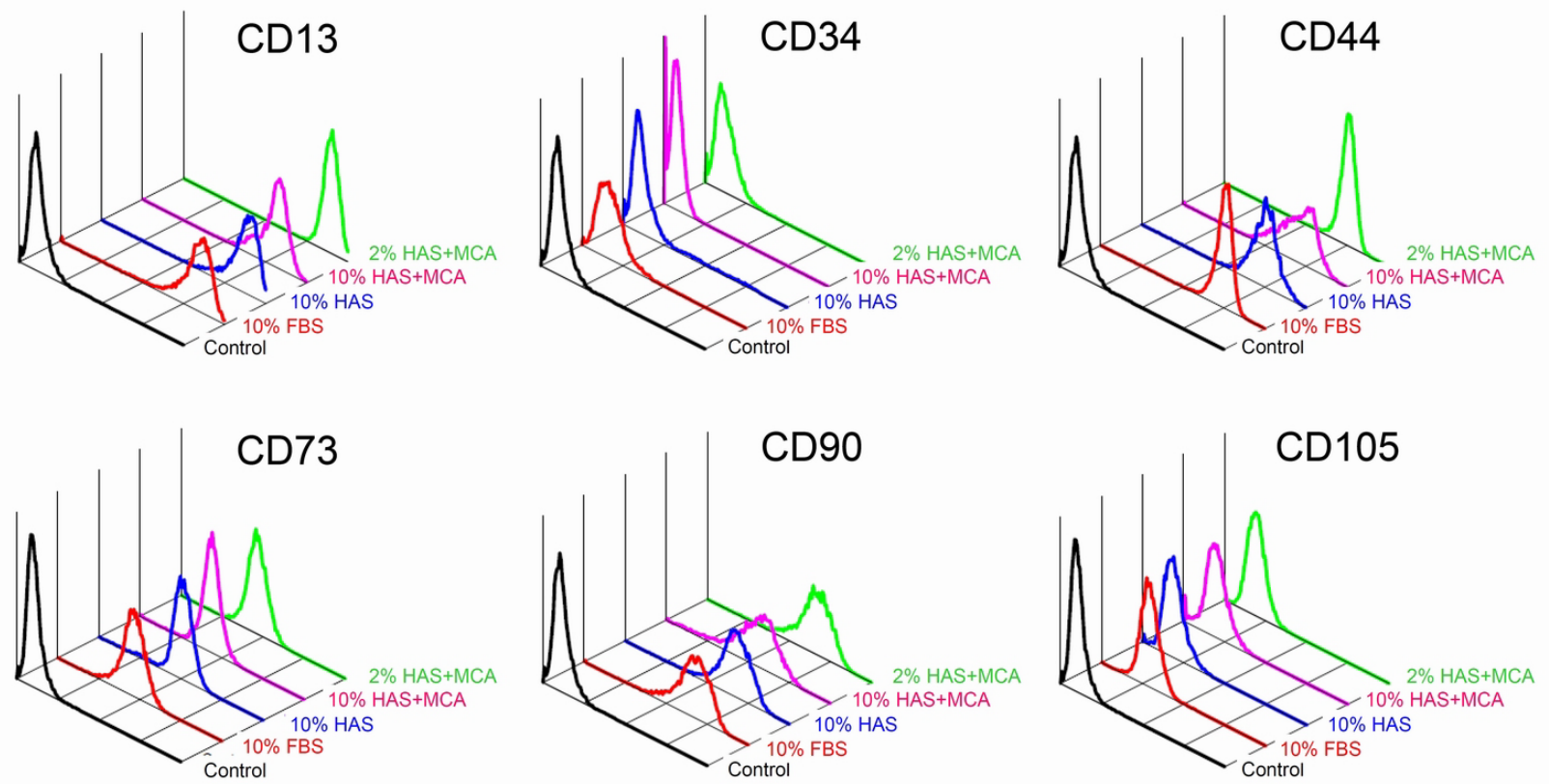

Figure 7: The phenotype of ADSCs at day 6 following culturing in respective culture media. Black lines indicate background (control) signals; colored lines represent the expression of each indicated cell surface markers during $(A)$ passage 1 , and $(B)$ passage 2.

is the first description of a semi-automated system to manufacture ADSCs from EFTs.

Since only very small amounts $(1 \%-5 \%)$ of SVF cells isolated from
AFT will become ADSCs, liposuction is not ideal for individuals with low BMI [7,9]. For these individuals, an enhanced SVF and ADSC extraction efficiency is required for effective cell therapy, where direct 
Citation: Sun LY, Li DK, Chen PJ, Ho YYJ, Kuo JS, et al. (2014) Expansion of Semi-Automatic Processed Human Adipose-Derived Stem Cells in Medium Supplemented with Autologous Serum and Antioxidants. J Stem Cell Res Ther 4: 193. doi:10.4172/2157-7633.1000193

A

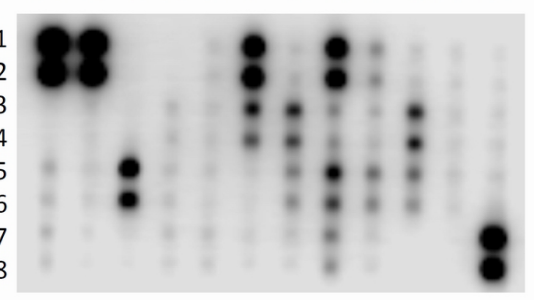

10\% HAS (Day4)

A B C D EF G H I J K L

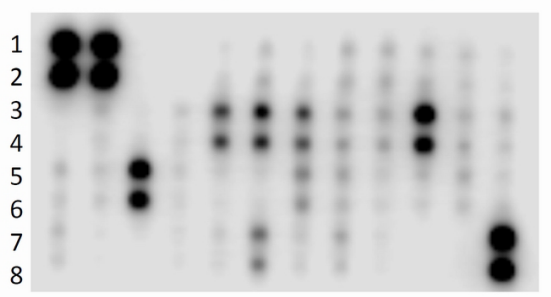

$10 \%$ HAS+MCA (Day4)

A B C D E F G H I J K L

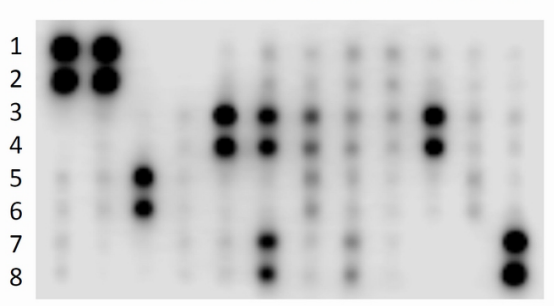

B

$10 \%$ HAS (Day0) vs. 10\% HAS (Day4)

\begin{tabular}{|c|c|c|c|c|c|c|c|c|c|c|c|c|}
\hline & A & B & C & D & $E$ & $\mathrm{~F}$ & G & $\mathrm{H}$ & 1 & J & K & L \\
\hline 1 & \multirow{2}{*}{ POS } & \multirow[b]{2}{*}{ POS } & \multirow[b]{2}{*}{ NEG } & \multirow[b]{2}{*}{ NEG } & \multirow[b]{2}{*}{ AREG } & \multirow[b]{2}{*}{ bFGF } & \multirow[b]{2}{*}{$\beta$-NGF } & \multirow[b]{2}{*}{ EGF } & \multirow[b]{2}{*}{ EGF R } & \multirow[b]{2}{*}{ FGF-4 } & \multirow[b]{2}{*}{ FGF- 6} & \multirow[b]{2}{*}{ FGF-7 } \\
\hline 2 & & & & & & & & & & & & \\
\hline 3 & \multirow{2}{*}{ GCSF } & \multirow{2}{*}{ GDNF } & \multirow{2}{*}{$\begin{array}{l}\text { GM- } \\
\text { CSF }\end{array}$} & \multirow{2}{*}{$\begin{array}{l}\text { HB- } \\
\text { EGF }\end{array}$} & \multirow{2}{*}{ HGF } & \multirow{2}{*}{$\begin{array}{c}\text { IGFBP- } \\
1\end{array}$} & \multirow{2}{*}{$\begin{array}{c}\text { IGFBP- } \\
2\end{array}$} & \multirow{2}{*}{$\begin{array}{c}\text { IGFBP- } \\
3\end{array}$} & \multirow{2}{*}{$\begin{array}{c}\text { IGFBP- } \\
4\end{array}$} & IGFBP- & \multirow{2}{*}{ IGF-I } & IGF-I \\
\hline 4 & & & & & & & & & & & & $S R$ \\
\hline 5 & \multirow{2}{*}{ IGF-II } & \multirow{2}{*}{ M-CSF } & \multirow{2}{*}{$\begin{array}{c}\text { M-CSF } \\
R\end{array}$} & \multirow{2}{*}{ NT-3 } & \multirow{2}{*}{ NT-4 } & \multirow{2}{*}{$\begin{array}{l}\text { PDGF } \\
R \alpha\end{array}$} & \multirow{2}{*}{$\begin{array}{c}\text { PDGF } \\
\text { R }\end{array}$} & \multirow{2}{*}{$\begin{array}{l}\text { PDGF- } \\
\text { AA }\end{array}$} & \multirow{2}{*}{$\begin{array}{c}\text { PDGF- } \\
A B\end{array}$} & PDGF- & \multirow{2}{*}{ PIGF } & \multirow{2}{*}{ SCF } \\
\hline 6 & & & & & & & & & & BB & & \\
\hline 7 & \multirow{2}{*}{ SCF R } & \multirow{2}{*}{ TGF- $\alpha$} & \multirow{2}{*}{$\begin{array}{c}\text { TGF- } \\
\beta 1\end{array}$} & \multirow{2}{*}{$\begin{array}{c}\text { TGF- } \\
\beta 2\end{array}$} & \multirow{2}{*}{$\begin{array}{c}\text { TGF- } \\
\beta 3\end{array}$} & YISC & VEGF & VEGF & VEGF- & 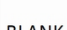 & & DOS \\
\hline 8 & & & & & & & R2 & R3 & D & DLAIV & DLAIVI & ros \\
\hline
\end{tabular}

$10 \%$ HAS (Day4) vs. 10\% HAS+MCA (Day4)

\begin{tabular}{|c|c|c|c|c|c|c|c|c|c|c|c|c|}
\hline & A & B & C & D & $E$ & $\mathrm{~F}$ & G & $\mathrm{H}$ & 1 & J & K & L \\
\hline$\frac{1}{2}$ & POS & POS & NEG & NEG & AREG & bFGF & b-NGF & EGF & EGF $R$ & FGF-4 & FGF-6 & FGF-7 \\
\hline 3 & GCSF & GDNF & $\begin{array}{l}\text { GM- } \\
\text { CSF }\end{array}$ & $\begin{array}{l}\text { HB- } \\
\text { EGF }\end{array}$ & HGF & $\begin{array}{c}\text { IGFBP- } \\
1\end{array}$ & $\begin{array}{c}\text { IGFBP- } \\
2\end{array}$ & $\begin{array}{c}\text { IGFBP- } \\
3\end{array}$ & $\begin{array}{c}\text { IGFBP- } \\
4\end{array}$ & $\begin{array}{c}\text { IGFBP- } \\
6\end{array}$ & IGF-I & $\begin{array}{c}\text { IGF-I } \\
\text { SR }\end{array}$ \\
\hline 6 & |GF-II & M-CSF & $\begin{array}{c}\text { M-CSF } \\
\text { R }\end{array}$ & NT-3 & NT-4 & $\begin{array}{c}\text { PDGF } \\
R \alpha\end{array}$ & $\begin{array}{c}\text { PDGF } \\
\text { R }\end{array}$ & $\begin{array}{l}\text { PDGF- } \\
\text { AA }\end{array}$ & $\begin{array}{c}\text { PDGF- } \\
\text { AB }\end{array}$ & $\begin{array}{c}\text { PDGF- } \\
\text { BB }\end{array}$ & PIGF & SCF \\
\hline$\frac{7}{8}$ & SCF R & TGF- $\alpha$ & $\begin{array}{c}\text { TGF- } \\
\beta 1\end{array}$ & $\begin{array}{c}\text { TGF- } \\
\beta 2\end{array}$ & $\begin{array}{c}\text { TGF- } \\
\beta 3\end{array}$ & VEGF & $\begin{array}{c}\text { VEGF } \\
\text { R2 }\end{array}$ & $\begin{array}{l}\text { VEGF } \\
\text { R3 }\end{array}$ & $\begin{array}{c}\text { VEGF- } \\
\text { D }\end{array}$ & BLANK & BLANK & POS \\
\hline
\end{tabular}

C

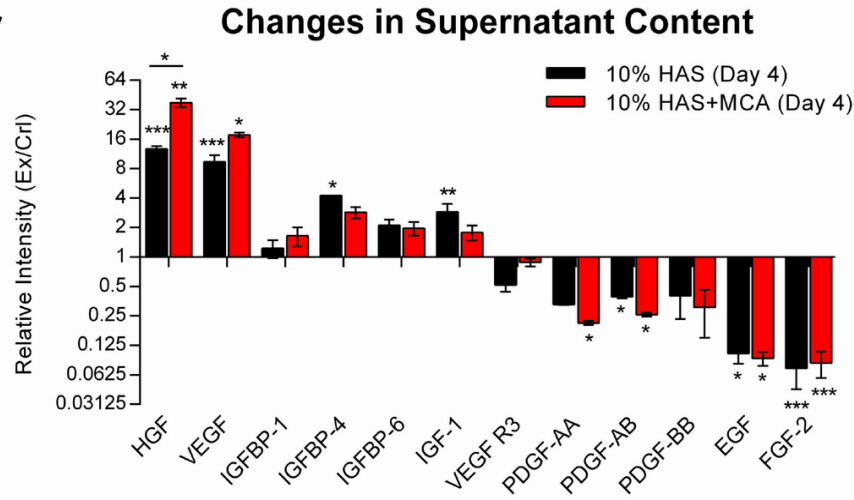

Figure 8: The cytokine profiles of the ADSCs exposed to the different culture media $(n=3)$. Supernatants harvested from the cultured ADSCs were compared by cytokine array on day 4. (A) The cytokine arrays. (B) Map of the cytokine arrays. Blue indicates reduction in the supernatant and orange indicates cytokine secretion. (C) Relative ratio of cytokine expression levels from cytokine array membranes. Cytokine and growth factor expression from culture supernatants were normalized against an internal positive control (POS) on the same membrane and presented as the relative intensity ratio of cultured, experimental (Ex) groups at day 4 to uncultured, control $(\mathrm{Crl})$ group at day $0(\mathrm{Ex} / \mathrm{Crl})$. Data are presented as mean $\pm \mathrm{SD}(\mathrm{n}=3)$. The relative ratios of less than 1 are reduction of content in the supernatant, and the relative ratios of greater than 1 are classified as secretion. ${ }^{*} p<0.05$. ${ }^{* *} p<0.01$. ${ }^{* \star *} p<0.005$.

excision of fat tissues has been found previously to increase cell yield [6]. Thus, processing of EFT by our semi-automatic protocol is inevitably necessary. Our study demonstrated that the total SVF cell yield of EFT $(\mathrm{n}=9)$ was $2.65 \pm 2.2 \times 10^{5} / \mathrm{ml}$ by surgical scissors and $3.53 \pm 2.2 \times 10^{5} /$ $\mathrm{ml}$ by tube dispersers. The cell viability was $66.22 \pm 14.12 \%$ by surgical scissors and $74.22 \pm 11.36 \%$ by tube dispersers, indicating that the semiautomatic method enhances the viable cell yields. Studies regarding the total SVF yield from both EFT and AFT are rarely reported in the literature. Although one study has reported total SVF cell yields of $1.44 \pm 1.62 \times 10^{6} / \mathrm{ml}$ from males $(\mathrm{n}=36)$ and $2.05 \pm 1.46 \times 10^{6} / \mathrm{ml}$ from females $(\mathrm{n}=78)$ [2], SVF yields obtained from AFT in our laboratory was $3.28 \pm 5.59 \times 10^{5} / \mathrm{ml}(\mathrm{n}=11)$ (data not published). The differences in cell yield may be due to differential cell counting methodology, where the large amount of red blood cells present in the SVF samples are more easily excluded using Propidium Iodide (PI) instead of the Trypan Blue dye. In comparison to the cell yields obtained from our AFT samples, cell extractions from EFT samples by our semi-automated method, on average, lead to higher cell yields. At the same time, fat tissue extraction by EFT is more suitable for individuals with low BMI.

Serum is the most variable factor in the expansion of ADSCs at clinical grade standard. The use of animal sera, such as FBS, in culture medium increases the risk of transmitting zoonotic or other infectious agents [20-22]. On the other hand, the cost of proprietary chemicallydefined, xeno-free SFM presents another barrier to the production of ADSCs for wide clinical applications. In fact, the clinical effects of SFM remain unclear. Some replacements of FBS such as pooled human 
serum, HAS or platelet lysate (PL) have been considered as alternatives for producing MSCs in clinical applications [24,40-42]. Although HAS exhibits batch-to-batch variability, it is still the safest option due to the elimination of the risk of contamination from xenogeneic or allogeneic products. In substitution for FBS, HAS and/or PL has been tested for ADSC cultures $[24,41]$. However, HAS and/or PL supplement may cause cell growth arrest and even cell death [20,41]. We had similar observations where HAS supplementation alone resulted in ADSC growth arrest on day 7 (Figure 3B), but the addition of MCA supported, and increased, the continual growth of ADSCs to the $7^{\text {th }}$ day (Figure 3C).

Cells must be retrieved in sufficient numbers for therapeutic efficacy $[2,43,44]$. In our previous study, we demonstrated that MCA promoted ADSCs to the S phase in the cell cycle by suppressing CDK inhibitors, p21 and p27, and resulted in rapid cell proliferation similar to that observed under hypoxic conditions [35]. In the present study, we found that the 10\% HAS+MCA-supplemented medium enhanced ADSCs proliferation in vitro as compared to the $10 \%$ HAS condition (Figure 3C). The addition of MCA also reduced the amount of HAS necessary for ADSC expansion (Figure 3D). Thus, our formulation facilitates rapid ADSC expansion for individuals who require urgent autologous cell transplantation.

In our previous study, medium containing FBS and MCA caused significant reduction in the expression of CD29, CD90 and CD105 in ADSCs, while at the same time enhanced their osteogenic and adipogenic differentiating potentials [35]. In the present study, we did not find significant differences in the expression level of surface markers on ADSCs grown in media supplemented with either HAS alone or HAS+MCA at passage 1 or 2. However, the expression levels of CD34, CD44 and CD90 on ADSCs grown in the HAS-supplemented medium were different to those cultured in the FBS-supplemented medium at passage 1. The expression levels of surface markers on ADSCs have been demonstrated to be associated with the differentiation potential of ADSCs $[45,46]$. The higher expression of CD44 (TGF- $\beta$ receptor) on ADSCs grown in the HAS-supplemented medium may explain the enhanced osteogenic (Figure 5) and chondrogenic potentials (Figure 6) [47].

ADSCs and their secretory factors such as VEGF, HGF and FGF-2 are known to be beneficial in skin repair and regeneration [48]. While hypoxia has been found to regulate the production of a variety of growth factors and enhance the paracrine effect of ADSCs to promote hair growth [49], we have found that MCA may also affect the paracrine and/or autocrine activities of ADSCs via changes of cytokine and growth factor content in the microenvironment (Figure 8). Our results showed that the $10 \%$ HAS+MCA supplement induced the reduction of PDGF-AA, PDGF-AB and PDGF-BB found in the supernatant during ADSCs proliferation that may be due to an enhanced uptake, binding to cell surface receptors, or degradation of cytokines, whereas the secretion of HGF and VEGF were enhanced (Figure 8C). To the best of our knowledge, this is the first report demonstrating that MCA can regulate the autocrine and/or paracrine activities in ADSCs.

We have developed a semi-automated process that is particularly suitable for isolating human ADSCs from small amounts of EFT and formulated a xeno-free medium using HAS (2 or 10\%) and MCA for their efficient expansion. The use of HAS and chemically-defined MCA comply with the GTP and GMP requirements for human tissues and cell products, respectively. These rapidly proliferating ADSCs have normal karyotypes and typical surface marker profiles, while maintaining stemness gene expression and differentiation potential. In summary, the combination of this novel semi-automated system with the HAS+MCA-supplemented medium may provide a better solution for the clinical applications of small amounts of EFT for regenerative medicine and tissue engineering.

\section{Competing Interests}

The authors declare that they have no competing interests.

\section{Conflict of Interest}

The authors report no conflicts of interest and are responsible for the content and writing of the paper.

\section{Funding}

This study was supported by the Buddhist Tzu Chi General Hospital (grants TCRD-I101-05-01, TCRD-I101-05-02, and TCRD-I101-05-03) and the Min-Sheng Hospital (grant MS2011016)

\section{References}

1. Riordan NH, Ichim TE, Min WP, Wang H, Solano F, et al. (2009) Non-expanded adipose stromal vascular fraction cell therapy for multiple sclerosis. J Transl Med 7: 29.[PubMed]

2. Faustini M, Bucco M, Chlapanidas T, Lucconi G, Marazzi M, et al. (2010) Nonexpanded mesenchymal stem cells for regenerative medicine: yield in stromal vascular fraction from adipose tissues. Tissue Eng Part C Methods 16(6): 1515-1521.[PubMed]

3. Ho JH, Ma WH, Tseng TC, Chen YF, Chen MH, et al. (2011) Isolation and characterization of multi-potent stem cells from human orbital fat tissues. Tissue Eng Part A 17(1-2): 255-266.[PubMed]

4. Neupane M, Chang CC, Kiupel M,Yuzbasiyan-Gurkan V (2008) Isolation and characterization of canine adipose-derived mesenchymal stem cells. Tissue Eng Part A 14: 1007-1015.[PubMed]

5. Planat-Benard V, Silvestre JS, Cousin B, Andre M, Nibbelink M, et al. (2004) Plasticity of human adipose lineage cells toward endothelial cells: physiological and therapeutic perspectives. Circulation 109(5): 656-663.[PubMed]

6. Matsumoto D, Sato K, Gonda K, Takaki Y, Shigeura T, et al. (2006) Cellassisted lipotransfer: supportive use of human adipose-derived cells for sof tissue augmentation with lipoinjection. Tissue Eng 12(12): 3375-3382.[PubMed]

7. Yoshimura K, Sato K, Aoi N, Kurita M, Hirohi T, et al. (2008) Cell-assisted lipotransfer for cosmetic breast augmentation: supportive use of adiposederived stem/stromal cells. Aesthetic Plast Surg 32(1): 48-55; discussion 5647.[PubMed]

8. Yoshimura K, Sato K, Aoi N, Kurita M, Inoue K, et al. (2008) Cell-assisted lipotransfer for facial lipoatrophy: efficacy of clinical use of adipose-derived stem cells. Dermatol Surg 34(9): 1178-1185.[PubMed]

9. Yoshimura K, Asano Y, Aoi N, Kurita M, Oshima Y, et al. (2010) Progenitorenriched adipose tissue transplantation as rescue for breast implant complications. Breast J 16(2): 169-175.[PubMed]

10. Kim M, Kim I, Lee SK, Bang SI, Lim SY (2011) Clinical trial of autologous differentiated adipocytes from stem cells derived from human adipose tissue. Dermatol Surg 37(6): 750-759.[PubMed]

11. Lendeckel S, Jodicke A, Christophis P, Heidinger K, Wolff J, et al. (2004) Autologous stem cells (adipose) and fibrin glue used to treat widespread traumatic calvarial defects: case report. J Craniomaxillofac Surg 32(6): 370 373.[PubMed]

12. Gimble JM, Guilak F, Bunnell BA (2010) Clinical and preclinical translation of cell-based therapies using adipose tissue-derived cells. Stem Cell Res Ther 1(2): 19.[PubMed]

13. Casteilla L, Planat-Benard V, Laharrague P, Cousin B (2011) Adipose-derived stromal cells: Their identity and uses in clinical trials, an update. World J Stem Cells 3(4): 25-33.[PubMed]

14. Griesche N, Luttmann W, Luttmann A, Stammermann T, Geiger H, et al. (2010) A simple modification of the separation method reduces heterogeneity of adipose-derived stem cells. Cells Tissues Organs 192(2): 106-115.[PubMed]

15. Zhang S, Espandar L, Imhof KM, Bunnell BA (2013) Differentiation of Human 
Adipose-derived Stem Cells along the Keratocyte Lineage. J Clin Exp Ophthalmol 4(270).[PubMed]

16. Lin KJ, Loi MX, Lien GS, Cheng CF, Pao HY, et al. (2013) Topical administration of orbital fat-derived stem cells promotes corneal tissue regeneration. Stem Cell Res Ther 4(3): 72.[PubMed]

17. Niada S, Ferreira LM, Arrigoni E, Addis A, Campagnol M, et al. (2013) Porcine adipose-derived stem cells from buccal fat pad and subcutaneous adipose tissue for future preclinical studies in oral surgery. Stem Cell Res Ther 4(6) 148.[PubMed]

18. Farre-Guasch E, Marti-Page C, Hernadez-Alfaro F, Klein-Nulend J, Casals N (2010) Buccal fat pad, an oral access source of human adipose stem cells with potential for osteochondral tissue engineering: an in vitro study. Tissue Eng Part C Methods 16: 1083-1094.[PubMed]

19. Lin K, Matsubara Y, Masuda Y, Togashi K, Ohno T, et al. (2008) Characterization of adipose tissue-derived cells isolated with the Celution system. Cytotherapy 10(4): 417-426.[PubMed]

20. Spees JL, Gregory CA, Singh H, Tucker HA, Peister A, et al. (2004) Internalized antigens must be removed to prepare hypoimmunogenic mesenchymal stem cells for cell and gene therapy. Mol Ther 9(5): 747-756.[PubMed]

21. Sundin M, Ringden O, Sundberg B, Nava S, Gotherstrom C, et al. (2007) No alloantibodies against mesenchymal stromal cells, but presence of anti-fetal calf serum antibodies, after transplantation in allogeneic hematopoietic stem cell recipients. Haematologica 92(9): 1208-1215.[PubMed]

22. Santos FD, Andrade PZ, Abecasis MM, Gimble JM, Chase LG, et al. (2011) Toward a Clinical-Grade Expansion of Mesenchymal Stem Cells from Human Sources: A Microcarrier-Based Culture System Under Xeno-Free Conditions. Tissue Eng Part C Methods 17(12): 1201-1210.[PubMed]

23. Di Bernardo G, Messina G, Capasso S, Del Gaudio S, Cipollaro M, et al. (2014) Sera of overweight people promote in vitro adipocyte differentiation of bone marrow stromal cells. Stem Cell Res Ther 5(1): 4.[PubMed]

24. Perez-Ilzarbe M, Diez-Campelo M, Aranda P, Tabera S, Lopez T, et al. (2009) Comparison of ex vivo expansion culture conditions of mesenchymal stem cells for human cell therapy. Transfusion 49(9): 1901-1910.[PubMed]

25. Valencic E, Loganes C, Cesana S, Piscianz E, Gaipa G, et al. (2014) Inhibition of mesenchymal stromal cells by pre-activated lymphocytes and their culture media. Stem Cell Res Ther 5(1): 3.[PubMed]

26. Even MS, Sandusky CB, Barnard ND (2006) Serum-free hybridoma culture: ethical, scientific and safety considerations. Trends Biotechnol 24(3): 105-108. [PubMed]

27. Lindroos B, Boucher S, Chase L, Kuokkanen H, Huhtala H, et al. (2009) Serumfree, xeno-free culture media maintain the proliferation rate and multipotentiality of adipose stem cells in vitro. Cytotherapy 11(7): 958-972.[PubMed]

28. Felka T, Schafer R, De Zwart P, Aicher WK (2010) Animal serum-free expansion and differentiation of human mesenchymal stromal cells. Cytotherapy 12(2): 143-153.[PubMed]

29. Hartmann I, Hollweck T, Haffner S, Krebs M, Meiser B, et al. (2010) Umbilical cord tissue-derived mesenchymal stem cells grow best under GMP-complian culture conditions and maintain their phenotypic and functional properties. J Immunol Methods 363(1): 80-89.[PubMed]

30. Pal R, Hanwate M, Jan M, Totey S (2009) Phenotypic and functional comparison of optimum culture conditions for upscaling of bone marrow-derived mesenchymal stem cells. J Tissue Eng Regen Med 3(3): 163-174.[PubMed]

31. Rajaraman G, White J, Tan KS, Ulrich D, Rosamilia A, et al. (2012) Optimization and Scale-up Culture of Human Endometrial Multipotent Mesenchymal Stroma Cells: Potential for Clinical Application. Tissue Eng Part C Methods 19: 80-92. [PubMed]

32. Jung S, Panchalingam KM, Rosenberg L, Behie LA (2012) Ex vivo expansion of human mesenchymal stem cells in defined serum-free media. Stem Cells Int 2012: 123030.[PubMed]
33. Chase LG, Yang S, Zachar V, Yang Z, Lakshmipathy U, et al. (2012) Development and characterization of a clinically compliant xeno-free culture medium in good manufacturing practice for human multipotent mesenchymal stem cells. Stem Cells Transl Med 1(10): 750-758.[PubMed]

34. Corotchi MC, Popa MA, Remes A, Sima LE, Gussi I, et al. (2013) Isolation method and xeno-free culture conditions influence multipotent differentiation capacity of human Wharton's jelly-derived mesenchymal stem cells. Stem Cell Res Ther 4(4): 81.[PubMed]

35. Sun LY, Pang CY, Li DK, Liao CH, Huang WC, et al. (2013) Antioxidants cause rapid expansion of human adipose-derived mesenchymal stem cells via CDK and CDK inhibitor regulation. J Biomed Sci 20(1): 53.[PubMed]

36. Lin PC, Chen YL, Chiu SC, Yu YL, Chen SP, et al. (2008) Orphan nuclear receptor, Nurr-77 was a possible target gene of butylidenephthalide chemotherapy on glioblastoma multiform brain tumor. J Neurochem 106(3): 1017-1026.[PubMed]

37. Tsai LP, Lee KF, Fang JS, Liu IY (2011) Molecular cytogenetic analysis and clinical manifestations of a case with de novo mosaic ring chromosome 7 . Mo Cytogenet 4(1): 5.[PubMed]

38. Sun LY, Hsieh DK, Yu TC, Chiu HT, Lu SF, et al. (2009) Effect of pulsed electromagnetic field on the proliferation and differentiation potential of human bone marrow mesenchymal stem cells. Bioelectromagnetics 30(4): 251-260. [PubMed]

39. Wang KH, Kao AP, Wangchen H, Wang FY, Chang CH, et al. (2008) Optimizing proliferation and characterization of multipotent stem cells from porcine adipose tissue. Biotechnol Appl Biochem 51(Pt): 159-166.[PubMed]

40. Honmou O, Houkin K, Matsunaga T, Niitsu Y, Ishiai S, et al. (2011) Intravenous administration of auto serum-expanded autologous mesenchymal stem cells in stroke. Brain 134(Pt6): 1790-1807.[PubMed]

41. Muller AM, Davenport M, Verrier S, Droeser R, Alini M, et al. (2009) Platelet lysate as a serum substitute for $2 \mathrm{D}$ static and $3 \mathrm{D}$ perfusion culture of stromal vascular fraction cells from human adipose tissue. Tissue Eng Part A 15(4): 869-875.[PubMed]

42. Van Pham P, Bui KH, Ngo DQ, Vu NB, Truong NH, et al. (2013) Activated platelet-rich plasma improves adipose-derived stem cell transplantation efficiency in injured articular cartilage. Stem Cell Res Ther 4(4): 91.[PubMed]

43. Badet L, Benhamou PY, Wojtusciszyn A, Baertschiger R, Milliat-Guittard L, et al. (2007) Expectations and strategies regarding islet transplantation: metabolic data from the GRAGIL 2 trial. Transplantation 84(1): 89-96.[PubMed]

44. Janssens S, Dubois C, Bogaert J, Theunissen K, Deroose C, et al. (2006) Autologous bone marrow-derived stem-cell transfer in patients with STsegment elevation myocardial infarction: double-blind, randomised controlled trial. Lancet 367(9505): 113-121.[PubMed]

45. De Francesco F, Tirino V, Desiderio V, Ferraro G, D'Andrea F, et al. (2009) Human CD34/CD90 ASCs are capable of growing as sphere clusters, producing high levels of VEGF and forming capillaries. PLoS One 4(8): e6537.[PubMed]

46. Traktuev DO, Merfeld-Clauss S, Li J, Kolonin M, Arap W, et al. (2008) A population of multipotent CD34-positive adipose stromal cells share pericyte and mesenchymal surface markers, reside in a periendothelial location, and stabilize endothelial networks. Circ Res 102(1): 77-85.[PubMed]

47. Lee HJ, Choi BH, Min BH, Park SR (2009) Changes in surface markers of human mesenchymal stem cells during the chondrogenic differentiation and dedifferentiation processes in vitro. Arthritis Rheum 60(8): 2325-2332.[PubMed]

48. Kim WS, Park BS, Sung JH (2009) The wound-healing and antioxidant effects of adipose-derived stem cells. Expert Opin Biol Ther 9(7): 879-887.[PubMed]

49. Park BS, Kim WS, Choi JS, Kim HK, Won JH, et al. (2010) Hair growth stimulated by conditioned medium of adipose-derived stem cells is enhanced by hypoxia: evidence of increased growth factor secretion. Biomed Res 31(1) 27-34.[PubMed] 